\title{
FAKTOR-FAKTOR YANG BERHUBUNGAN DENGAN KEPEMILIKAN JAMBAN SEHAT DI DESA SUNGAI ITIK KECAMATAN SADU KABUPATEN TANJUNG JABUNG TIMUR TAHUN 2021
}

\author{
Rizki Nur Amelia', Rd.Halim ${ }^{1}$, Usi Lanita ${ }^{1}$ \\ ${ }^{1}$ Program Studi IImu Kesehatan Masyarakat, FKIK Universitas Jambi \\ Email: rizkikimel@gmail.com
}

\begin{abstract}
A latrine is a building that is useful as a place for disposal and collection of feces which will later collect in a place and do not result in the emergence of various disease and environmental pollution. Sungai Itik Village is one village of access to healthy latrine was low only $56.78 \%$. Purpose this study is to determine factors associated with healthy latrine ownership in the Sungai Itik Village. This study used an observational method with a crosssectional design, population as many as 512 respondents and sample as many as 120 respondents taken by proportionate strafied random sampling. Data analysis technique using chi-square statistic test and for economic status variable using simple logistic regression test. There were $56.7 \%$ of respondents who do not have healthy latrines and there was a relationship between the knowledge $(P=0.000)$, economic status $(P=0.000)$, availability of clean water $(P=0.017)$ and the role of health workers $(P=0.000)$ on ownership of healthy latrines in Sungai Itik Village. The knowledge, economic status, availability of clean water and the role of health workers have a significant relationship to ownership of healthy latrines in Sungai Itik Village.
\end{abstract}

Keywords : Healthy Latrine, knowledge, economic status, availability of clean water, the role of health workers

\section{ABSTRAK}

Jamban merupakan bangunan yang berguna sebagai tempat pembuangan dan pengumpulan tinja yang nantinya terkumpul pada suatu tempat dan tidak mengakibatkan timbulnya berbagai macam penyakit dan pencemaran lingkungan. Desa Sungai Itik merupakan salah satu Desa akses jamban sehat tergolong rendah yaitu hanya $56,78 \%$. Penelitian ini bertujuan untuk mengetahui faktor-faktor yang berhubungan dengan kepemilikan jamban sehat di Desa Sungai Itik. Metode penelitian dengan desain Cross Sectional, Populasi sebanyak 120 responden dan sampel sebanyak 120 responden diambil dengan teknik Proporsionate Strafied Random Sampling. Teknik analisis data dengan menggunakan uji statistik chi-square dan variabel status ekonomi menggunakan uji regresi logistic sederhana. Hasil penelitian didapatkan terdapat $56,7 \%$ responden yang belum memiliki jamban sehat dan ada hubungan antara pengetahuan $(P=0,000)$, status ekonomi $(P=0,000)$, ketersediaan air bersih $(P$ $=0,017)$ dan peran petugas kesehatan $(P=0,000)$ terhadap kepemilikan jamban sehat di Desa Sungai Itik. Pengetahuan, status ekonomi, ketersediaan air bersih dan peran petugas kesehatan memiliki hubungan yang signifikan terhadap kepemilikan jamban sehat di Desa Sungai Itik.

Kata kunci: Jamban Sehat, Pengetahuan, Status Ekonomi, Ketersediaan Air Bersih, Peran Petugas Kesehatan 


\section{PENDAHULUAN}

Penyediaan jamban merupakan upaya yang dapat dilakukan dalam meningkatkan derajat kesehatan masyarakat berupa sanitasi dasar yang nantinya dapat menjaga kesehatan lingkungan. Bahan buangan berupa tinja harus mendapat perhatian khusus karna kebanyakan permasalahan di bidang kesehatan berupa berbagai bibit penyakit awalnya bersumber dari tinja. Tidak hanya itu, pembuangan tinja juga dapat menyebabkan pencemaran tanah, air, udara, serta permasalahan estetika. ${ }^{1}$

Tinja berperan sebagai wadah terhadap perkembangbiakan berbagai bibit penyakit, khususnya penyakit menular seperti: cacing, kuman (bakteri), dan virus. Yang mana bila tinja dibuang secara sembarangan, seperti di sungai, kolam, ataupun tempat lainnya tentu berbagai bibit penyakit bisa tersebar ke lingkungan yang nantinya akan kontak dengan manusia baik melalui udara, kontak langsung, maupun vektor seperti serangga dan bisa berakibat timbulnya berbagai masalah kesehatan serta ditakutkan akan menjadi wabah penyakit yang serius pada lingkungan masyarakat sekitar. ${ }^{2}$

Dalam Peraturan Menteri Kesehatan Nomor 3 Tahun 2014 menyebutkan bahwa STBM atau sanitasi total berbasis masyarakat ialah pemberdayaan masyarakat berupa pemicuan sebagai upaya untuk mengatasi permasalahan perilaku hygiene serta sanitasi.

Pelaksanaan Sanitasi Total Berbasis Masyarakat (STBM) merupakan bentuk perwujudan peningkatan derajat kesehatan masyarakat secara maksimal berupa kemandirian dalam saniter dan higienis. ${ }^{3}$ Demi mendukung capaian target Rencana Pembangunan Jangka Menengah Nasional (RPJMN) termasuk Universal Access 2019, di penghujung tahun 2019 setiap wilayah kelurahan/desa wajib melaksanakan STBM sebanyak $100 \%$, yang mana $50 \%$ diantaranya telah mencapai Open Defecation Free (ODF). ODF terverifikasi ialah apabila suatu penduduk ataupun komunitas sudah tidak lagi melakukan buang air besar secara sembarangan yang mana akan berakibat pada penyebaran penyakit menular dan didukung dengan proses verifikasi. ${ }^{4}$

Secara nasional pada tahun 2018, pencapaian persentase akses jamban berada pada angka $73.9 \%$ dari total keseluruhan provinsi di Indonesia dengan akses jamban tertinggi dicapai oleh Provinsi Yogyakarta yang sudah mencapai 100\% sedangkan yang terendah adalah Provinsi Maluku dengan 1\%. ${ }^{5}$ Pada tahun 2018 sebanyak 74,58\% masuk kategori rumah tangga yang memiliki akses sanitasi layak, termasuk akses sanitasi aman hanya mencapai $7,42 \%$. Sisanya sebanyak 9,36\% rumah tangga masih buang air besar sembarangan. Masih ada jarak total 7,58\% agar tercapainya target $15 \%$ berupa akses sanitasi aman di tahun 2024. Tersedianya akses sanitasi sangat berkorelasi dengan angka stunting dan penurunan angka pencemaran air bersumber dari limbah domestik. Adapun program yang dicanangkan RPJMN 2020-2024 merencanakan agar adanya peningkatan akses sanitasi layak rumah tangga menjadi 90\% (sudah termasuk $15 \%$ rumah tangga mempunyai akses sanitasi umum), menghilangkan angka BABS dan menurunkan angka stunting akibat akses sanitasi buruk menjadi kurang dari $10 \%{ }^{6}$

Pemanfaatan serta permasalahan jamban tidak banyak dipahami oleh masyarakat yang tentunya menjadi penyebab dari tingginya angka BABS, hal ini diakibatkan oleh beberapa faktor diantaranya: kebiasaan, tingkat pendidikan, penghasilan, dan pengetahuan itu 
sendiri. ${ }^{1}$ Lingkungan adalah penyebab paling berpengaruh pada kesehatan masyarakat maupun secara personal. Kondisi lingkungan kurang baik dalam segi prilaku masyarakat dan persyaratan kesehatan, tentunya akan merugikan masyarakat di perkotaan, khususnya yang berada di pedesaan secara teknologi, ekonomi, maupun kesehatan. Kondisi lingkungan yang mempengaruhi kesehatan disini yaitu tercemarnya kualitas air bersih, kondisi rumah, ketersediaan jamban, serta lingkungan bermasyarakat. Sanitasi serta penyediaan air bersih merupakan kebutuhan pokok masyarakat. Sebagaimana tertera dalam Sustainabel Development Goals (SDGs) poin lingkungan hidup, menjamin masyarakat mendapatkan akses sanitasi berupa jamban sehat dan kemudahan mendapatkan air bersih. Target dunia melalui pernyataan tersebut ialah tercapainya di tahun 2030 sehingga masyarakat terjamin kebersihan dan sanitasinya dengan tidak lagi melakukan BABS pada tempat terbuka. ${ }^{7}$

Data profil STBM Nasional

Kementerian Kesehatan Republik Indonesia tahun 2019 Provinsi Jambi menunjukkan bahwa rata-rata akses kepemilikan jamban adalah 82,79\%. Kabupaten Tanjung Jabung Timur berada pada urutan pertama dengan akses kepemilikan jamban paling rendah di Provinsi Jambi yaitu 74,38\%. Kecamatan Sadu merupakan Kecamatan dengan akses kepemilikan jamban terendah di Kabupaten Tanjung Jabung Timur yakni hanya 56,89\%. Sungai Itik merupakan salah satu desa di Kecamatan Sadu yang sudah dilakukan Pemicuan STBM oleh petugas kesehatan, akan tetapi akses jamban di Sungai Itik masih tergolong rendah yaitu hanya $56,78 \%$ dari 512 Kepala Keluarga. Sedangkan akses jamban di
Sungai Itik sebelum dilakukan pemicuan STBM yaitu $56,69 \%$ yang berarti hanya meningkat $0,09 \%$ setelah dilakukan pemicuan STBM. ${ }^{8}$ Belum diketahui pasti faktor apa saja yang berhubungan dengan rendahnya kepemilikan jamban sehat di Desa tersebut. Untuk mengatasi dampak buruk kepemilikan jamban bagi kesehatan masyarakat dan berdasarkan penelusuran oleh peneliti belum pernah dilakukan penelitian sejenis untuk menjawab faktor yang berhubungan dengan kepemilikan jamban di Desa Sungai Itik.

Berdasarkan latar belakang tersebut, maka peneliti tertarik untuk melakukan penelitian yang berjudul "Faktor-faktor yang Berhubungan dengan Kepemilikan Jamban di Desa Sungai Itik Kecamatan Sadu Kabupaten Tanjung Jabung Timur tahun 2021”.

\section{METODE}

Jenis penelitian yang digunakan pada penelitian ini yaitu penelitian observasional yang menggunakan pendekatan kuantitatif dengan rancangan penelitian cross sectional yang bertujuan untuk mengetahui hubungan antara faktor risiko (independen) dengan akibat atau efek (dependen) yang mana pengumpulan data dilakukan dalam satu waktu antara variabel independen dengan dependen.

Penelitian dilaksanakan di Desa Sungai Itik Kecamatan Sadu pada bulan Januari 2021. Populasi pada penelitian ini berjumlah $512 \mathrm{KK}$ mencakup seluruh kepala keluarga di Desa Sungai Itik Kecamatan Sadu Kabupaten Tanjung Jabung Timur. Pengambilan sampel menggunakan teknik proportionate strafied random sampling yang dipilih dari proporsi masing-masing dusun yang memenuhi kriteria inklusi dan eksklusi yang berjumlah 120 sampel. Teknik analisis data dengan menggunakan uji statistik chi square 
dan untuk variabel status ekonomi menggunakan uji regresi logistik sederhana.

\section{HASIL}

Berdasarkan hasil penelitian tentang faktor-faktor yang berhubungan dengan kepemilikan jamban sehat di Desa Sungai Itik Kecamatan Sadu Kabupaten Tanjung Jabung Timur didapatkan karakteristik responden yang ditunjukkan pada tabel dibawah ini:

Tabel 1. Karakteristik Responden

\begin{tabular}{lcc}
\hline Karakteristik & Frekuensi & Persentase \\
\hline Umur (tahun) & 97 & $80,7 \%$ \\
$<40$ & 23 & $19,2 \%$ \\
$\geq 40$ & & \\
\hline Jenis Kelamin & 54 & $45,0 \%$ \\
Laki-laki & 66 & $55,0 \%$ \\
Perempuan & & \\
\hline Pekerjaan & 5 & $4,2 \%$ \\
PNS & 10 & $8,3 \%$ \\
Honorer & 34 & $28,3 \%$ \\
Petani & 4 & $3,3 \%$ \\
Nelayan & 27 & $22,5 \%$ \\
Wiraswasta & 9 & $7,5 \%$ \\
Pelajar/Mahasiswa & 31 & $25,8 \%$ \\
IRT & & \\
\hline Pendidikan & 4 & $3,3 \%$ \\
Tidak Tamat SD & 19 & $15,8 \%$ \\
Sekolah Dasar & 72 & $60,0 \%$ \\
Sekolah & 25 & $20,8 \%$ \\
Menengah & \\
Perguruan Tinggi & Sumber: Data Primer 2021 & \\
\hline
\end{tabular}

Berdasarkan tabel 1 dapat diketahui bahwa sebagian besar responden berusia kurang dari 40 tahun yakni sebanyak $80,8 \%$, responden yang berjenis kelamin perempuan lebih banyak dari pada jenis kelamin laki-laki yakni perempuan sebanyak $55,0 \%$, mayoritas pekerjaan responden adalah sebagai petani yaitu $28,3 \%$ dan sebagian besar responden menempuh pendidikan hingga sekolah menengah yaitu sebanyak $60,0 \%$.

Tabel 2. Analisis Univariat

\begin{tabular}{lcc}
\hline \multicolumn{1}{c}{ Variabel } & Frekuensi & Persentase \\
\hline Kepemilikan & & \\
Jamban Sehat & & \\
Tidak Memiliki & 68 & $56,7 \%$ \\
Memiliki & 52 & $43,3 \%$ \\
\hline Pengetahuan & & \\
Kurang & 55 & $45,8 \%$
\end{tabular}




\begin{tabular}{lcc} 
Baik & 65 & $54,2 \%$ \\
\hline Status Ekonomi & 70 & $58,3 \%$ \\
Rendah & 13 & $10,8 \%$ \\
Sedang & 37 & $30,8 \%$ \\
Tinggi & & \\
\hline Ketersediaan Air & & \\
Bersih & 22 & $18,3 \%$ \\
Tidak Tersedia & 98 & $81,7 \%$ \\
Tersedia & & \\
\hline Peran Petugas & & $54,2 \%$ \\
Kesehatan & 65 & $45,8 \%$ \\
Tidak Berperan & 55 & \\
Berperan & & \\
\hline \multicolumn{1}{c}{ Sumber: Data Primer 2021} &
\end{tabular}

Berdasarkan tabel 2 diatas dapat diketahui bahwa sebanyak 56,7\% responden tidak memiliki jamban sehat, $45,8 \%$ responden memiliki pengetahuan rendah, $58,3 \%$ memiliki status ekonomi rendah, $18,3 \%$ responden tidak tersedia air bersih dan $54,2 \%$ responden mengatakan petugas kesehatan tidak berperan.

Hasil penelitian menggunakan analisis bivariat untuk mengetahui apakah ada hubungan antara pengetahuan, status ekonomi, ketersediaan air bersih dan peran petugas kesehatan dengan kepemilikan jamban di Desa Sungai Itik Kecamatan Sadu Kabupaten Tanjung Jabung Timur Tahun 2021. Adapun uji yang digunakan yaitu uji statistik chisquare dengan batas kemaknaan $\alpha<0,05$. Dikatakan ada hubungan yang signifikan secara statistik jika diperoleh nilai $p$ value $<0,5$.

Tabel 3 Analisis Bivariat

\begin{tabular}{|c|c|c|c|c|c|c|c|c|}
\hline \multirow{3}{*}{ Variabel } & \multicolumn{4}{|c|}{ Kepemilikan Jamban Sehat } & & & \multirow{3}{*}{ P Value } & \multirow{3}{*}{$\begin{array}{c}\text { PR } \\
(95 \% \mathrm{Cl})\end{array}$} \\
\hline & \multicolumn{2}{|c|}{ Tidak Memiliki } & \multicolumn{2}{|c|}{ Memiliki } & \multicolumn{2}{|c|}{ Total } & & \\
\hline & $n$ & $\%$ & $\mathbf{n}$ & $\%$ & $\mathbf{n}$ & $\%$ & & \\
\hline Pengetahuan & & & & & & & & 41,294 \\
\hline Kurang & 54 & 98,2 & 1 & 1,8 & 55 & 100 & 0,000 & $(5,906-$ \\
\hline Baik & 14 & 21,5 & 51 & 78,5 & 65 & 100 & & $288,737)$ \\
\hline \multicolumn{9}{|l|}{ Status Ekonomi } \\
\hline Rendah & 52 & 74,3 & 18 & 25,7 & 70 & 100 & \multirow{3}{*}{0,000} & \multirow{3}{*}{$\begin{array}{c}3,138 \\
(1,976- \\
4,983)\end{array}$} \\
\hline Sedang & 8 & 61,5 & 5 & 38,5 & 13 & 100 & & \\
\hline Tinggi & 8 & 21,6 & 29 & 78,4 & 37 & 100 & & \\
\hline \multicolumn{7}{|l|}{$\begin{array}{l}\text { Ketersediaan Air } \\
\text { Bersih }\end{array}$} & & \multirow{3}{*}{$\begin{array}{c}3,441 \\
(1,239- \\
9,557)\end{array}$} \\
\hline Tidak Tersedia & 18 & 81,8 & 4 & 18,2 & 33 & 100 & 0,017 & \\
\hline Tersedia & 50 & 51,0 & 48 & 49,0 & 98 & 100 & & \\
\hline \multicolumn{7}{|l|}{$\begin{array}{l}\text { Peran Petugas } \\
\text { Kesehatan }\end{array}$} & & \multirow{3}{*}{$\begin{array}{c}2,159 \\
(1,420- \\
3,283)\end{array}$} \\
\hline Tidak Berperan & 48 & 73,8 & 17 & 26,2 & 65 & 100 & 0,000 & \\
\hline Berperan & 20 & 36,4 & 35 & 63,3 & 55 & 100 & & \\
\hline
\end{tabular}


Berdasarkan uji statistik pada tabel 3 didapatkan nilai $p$ value $<0,05$ pada pengetahuan $(p=0,000)$, status ekonomi $(p=0,000)$, ketersediaan air bersih $(p=0,017)$ dan peran petugas kesehatan $(p=0,000)$ yang menunjukkan bahwa terdapat hubungan yang bermakna antara pengetahuan, status ekonomi, ketersediaan air bersih dan peran petugas kesehatan dengan kepemilikan jamban di Desa Sungai Itik Kecamatan Sadu Kabupaten Tanjuung Jabung Timur.

\section{PEMBAHASAN}

1. Hubungan Pengetahuan dengan Kepemilikan Jamban Sehat di Desa Sungai Itik Kecamatan Sadu Kabupaten Tanjung Jabung Timur Tahun 2021

Hasil penelitian menunjukkan bahwa terdapat hubungan yang signifikan antara pengetahuan dengan kepemilikan jamban sehat di Desa Sungai Itik Kecamatan Sadu Kabupaten Tanjung Jabung Timur dengan $\mathrm{p}$ value $=0,000<\alpha$ dan menunjukkan nilai Prevalence Ratio (PR) sebesar 41,294 dengan nilai Confidence Interval 95\% menunjukkan bahwa responden yang memiliki pengetahuan kurang memiliki resiko 41,294 kali untuk tidak memiliki jamban sehat.

Dalam penelitian ini terdapat $45,8 \%$ responden memiliki pengetahuan yang kurang dan berdasarkan distribusi tiap pertanyaan, terdapat 93,3\% yang tidak mengetahui jarak lubang jamban dengan sumber air bersih/sumur. Responden yang mempunyai tingkat pengetahuan kurang dikarenakan kurangnya informasi yang mereka peroleh mengenai sanitasi lingkungan terutama kepemilikan jamban sehat serta bagaimana kondisi jamban dikategorikan jamban sehat. Mereka hanya mengetahui bahwa tidak baik BAB di sembarang tempat, tetapi tidak memikirkan bagaimana kondisi sanitasi jamban yang memenuhi persyaratan kesehatan. Dalam hal ini, sebagian besar responden hanya membangun sarana tanpa memikirkan persyaratan kesehatan. Akan tetapi, ada juga beberapa responden yang memiliki pengetahuan baik namun tidak memiliki jamban sehat. Hal ini dapat terjadi dikarenakan mereka tidak mempraktikkan apa yang mereka ketahui di kehidupan sehari-hari.

Hal ini didukung dengan penelitian yang dilakukan Nofitry dan Agustin pada tahun 2017 yang menyebutkan bahwa nilai $p$ value $=0,000<0,05$ yang berarti ada hubungan antara pengetahuan dengan kepemilikan jamban sehat. Tingginya tingkat pengetahuan tentang akibat dari penyakit tertentu berbanding lurus dengan usaha preventif yang dilakukan, oleh karena itu perilaku yang tidak dilandasi pengetahuan, tidak lebih baik jika dibandingkan dengan perilaku yang dilandasi oleh pengetahuan. $^{7}$

Hasil observasi di lapangan peneliti juga menemukan jamban yang tidak memenuhi syarat dikatakan jamban sehat seperti tidak adanya atap pelindung, yang mana berdasarkan distribusi kuesioner terdapat $65,8 \%$ responden yang tidak tahu bagian jamban terdiri atas rumah jamban, dudukan jamban dan penampung tinja sehingga banyak ditemukan jamban dalam kondisi tidak ada atap dan juga tidak ada penampung tinja yang mana tinja langsung cemplung ke sungai. Selain itu, 58,3\% responden tidak tahu bagaimana cara memutus rantai penularan penyakit dari tinja sehingga tidak dilakukannya pencegahan untuk memutus rantai penularan penyakit dari tinja seperti tidak peduli dengan kondisi jamban yang dimiliki walaupun tidak memenuhi syarat dikatakan jamban sehat.

Hasil penelitian yang sama juga disebutkan oleh Putra dan Selviana tahun 2017 yang menunjukkan bahwa perilaku yang positif dimiliki oleh keluarga yang mempunyai pengetahuan baik terhadap akibat buruknya apabila tidak memiliki jamban sehat, begitupun sebaliknya. Dengan kata lain, ada hubungan antara kepemilikan jamban sehat dengan tingkat pengetahuan seseorang. ${ }^{9}$ Penelitian ini juga didukung penelitian yang dilakukan oleh Hayana dkk tahun 2020 yang menunjukkan bahwa ada hubungan antara pengetahuan dengan kepemilikan jamban di Kelurahan Kampung Baru Kota Pekan Baru. ${ }^{10}$

Berdasarkan hasil penelitian, usaha yang bisa dilakukan agar pengetahuan masyarakat meningkat tentang pentingnya kepemilikan jamban sehat yaitu 
dengan diadakannya penyuluhan, diskusi kelompok, pembagian leaflet atau poster oleh petugas kesehatan mengenai pentingnya kepemilikan jamban sehat, bagaimana kondisi jamban dikatakan jamban sehat, bagaimana cara memutus rantai penularan penyakit dari tinja serta dampak yang ditimbulkan jika tidak memiliki akses sanitasi terutama jamban yang tidak memenuhi persyaratan kesehatan.

2. Hubungan Status Ekonomi dengan Kepemilikan Jamban Sehat di Desa Sungai Itik Kecamatan Sadu Kabupaten Tanjung Jabung Timur Tahun 2021

Hasil penelitian ini menunjukkan bahwa terdapat hubungan yang signifikan antara status ekonomi dengan kepemilikan jamban sehat di Desa Sungai Itik Kecamatan Sadu Kabupaten Tanjung Jabung Timur dengan nilai $\mathrm{p}$ value $<\alpha$ dan menunjukkan nlai Prevalence Ratio (PR) sebesar 3,138 dengan nlai Confidence Interval 95\% menunjukkan bahwa responden yang memiliki pengetahuan kurang memiliki resiko 3,138 kali untuk tidak memiliki jamban sehat.

Hal ini disebabkan bahwa rata-rata responden yang termasuk kategori status ekonomi rendah bekerja sebagai petani. Yang mana penghasilan sebagai seorang petani sangat tidak menentu dikarenakan harga hasil tani yang naik turun. Petani di Desa Sungai Itik ini ada yang bekerja di kebun sendiri dan adapula yang mendapat upah bekerja di kebun orang lain dengan rata-rata penghasilan kurang dari Rp. 1.500.000 per bulan sehingga masyarakat lebih mengutamakan dalam pemenuhan kebutuhan pokok. Kemudian, pekerjaan lain masyarakat Desa Sungai Itik selain sebagai petani yaitu sebagai nelayan, wiraswasta, PNS, pegawai honorer dan adapula yang tidak bekerja.

Menurut Putra dan Selviana tahun 2017, Pelayanan kesehatan yang bermutu lebih banyak digunakan oleh masyarakat dengan status ekonomi tinggi, sebaliknya pemeliharaan serta pelayanan kesehatan jarang dilirik oleh masyarakat dengan status ekonomi menengah kebawah diakibatkan ketidakmampuan dalam membayar ongkos transportasi dan juga obat-obatan serta pelayanan kesehatan. Dengan kata lain kemudahan untuk merubah perilaku seseorang dipengaruhi oleh tingginya status ekonomi orang tersebut. ${ }^{9}$

Status ekonomi suatu keluarga sangat berpengaruh terhadap kepemilikan serta pemanfaatan jamban sehat di rumah. Hal ini didukung oleh penelitian Kamria yang menunjukkan bahwa ada hubungan yang bermakna antara tingkat pendapatan dengan perilaku BABS. Hasil penelitian yang sama juga didapatkan oleh Syahrir dkk pada tahun 2019 yaitu terdapat hubungan yang bermakna antara pendapatan dengan kepemilikan jamban keluarga dengan nilai $p=0,025<0,05$. Tinggi rendahnya pendapatan keluarga sangat mempengaruhi bagaimana dalam memenuhi kebutuhan sehari-hari mereka. ${ }^{1}$

Penelitian ini juga didukung penelitian yang dilakukan oleh Novitry dan Agustin tahun 2017 yang didapatkan ada hubungan yang bermakna antara pendapatan keluarga dengan kepemilikan jamban sehat di Desa Sukomulyo Puskesmas Kotabaru Martapura. ${ }^{7}$ Selain itu, penelitian ini juga didukung oleh penelitian Hayana dkk tahun 2020 yang didapatkan bahwa ada hubungan antara pendapatan dengan kepemilian jamban denga $p$ value $=0,008<0,05$. Tingkat pendapatan sangat mempengaruhi keadaan seseorang. Tingkat pendapatan yang rendah dapat mempengaruhi kepemilikan jamban dan sangat berisiko terhadap masyarakat yang tidak memiliki jamban dengan terjangkitnya suatu penyakit. ${ }^{10}$

Maka dari itu dapat disimpulkan bahwa status ekonomi sangat mempengaruhi dalam kepemilikan jamban sehat dikarenakan masyarakat yang memiliki tingkat ekonomi yang tinggi lebih memungkinkan untuk mengakses fasilitas sanitasi dibandingkan dengan tingkat ekonomi rendah. Upaya yang dapat dilakukan yaitu dengan mengadakan program arisan jamban sehat bagi keluarga yang kurang mampu agar dapat membangun jamban sehat di rumah.

3. Hubungan Ketersediaan Air Bersih dengan Kepemilikan Jamban Sehat di Desa Sungai Itik 
Kecamatan Sadu Kabupaten Tanjung Jabung Timur Tahun 2021

Hasil penelitian ini menemukan bahwa terdapat hubungan yang signifikan antara ketersediaan air bersih dengan kepemilikan jamban sehat di Desa Sungai Itik Kecamatan Sadu Kabupaten Tanjung Jabung Timur dengan nilai $\mathrm{p}$ value $<\alpha$ dan menunjukkan nilai Prevalence Ratio (PR) sebesar 3,441 (PR > 1) dengan nlai Confidence Interval 95\% menunjukkan bahwa responden yang tidak tersedia air bersih memiliki resiko 3,441 kali untuk tidak memiliki jamban sehat. Hasil observasi menunjukkan bahwa sarana air bersih pada masyarakat di Desa Sungai Itik sebagian besar sudah memenuhi syarat yaitu 98 responden $(81,7 \%)$, sedangkan yang tidak memenuhi syarat air bersih yaitu 22 responden (18,3\%). Dari hasil observasi juga didapatkan bahwa tidak ada responden yang menggunakan sumber air dari sungai walaupun kebanyakan rumah dipinggir sungai. Namun ditemukan ada beberapa sumber air bersih yang digunakan responden tidak memenuhi syarat seperti kualitas fisik air yang tidak sesuai, ada jamban pada radius 10 meter di sekitar sumur, saluran pembuangan air limbah tidak ada dan lain sebagainya. Maka dari itu, walaupun tidak menggunakan air sungai tetapi harus tetap diperhatikan lagi syarat air bersih yang bersumber dari sumur tersebut.

Sebagaimana yang telah diatur dalam UndangUndang Republik Indonesia Nomor 17 tahun 2019 tentang sumber daya air, air merupakan kebutuhan yang amat penting bagi kehidupan sehari-hari. Air bersih yang diperlukan untuk jamban dalam sehari agar dapat menunjang kenyamanan saat menggunakan jamban sehat adalah sebanyak 45 liter/orang/hari, maka dari itu sebaiknya sumber air bersih tidak terlalu jauh sehingga lebih memudahkan seseorang untuk mengakses air bersih. ${ }^{11}$

Ketersediaan air bersih merupakan faktor pendorong untuk perilaku hidup sehat yang sangat mendukung masyarakat untuk memiliki jamban sehat dikarenakan dengan tersedianya air bersih maka akan memungkinkan seseorang untuk lebih menjaga kebersihan diri. Hal ini didukung dengan penelitian yang dilakukan Hayana dkk tahun 2020 diperoleh bahwa adanya hubungan faktor ketersediaan air bersih dengan cakupan kepemilikan jamban di Kelurahan Kampung Baru dengan uji statistik $\mathrm{p}$ value $=0,004<0,005 .^{9}$

Hasil penelitian yang sama juga didapatkan oleh Mukhlasin dan Solihuding pada tahun 2020 diperoleh bahwa ketersediaan air bersih sangat berpengaruh terhadap kepemilikan jamban, hal tersebut terlihat bahwa kepemilikan jamban mayoritas didominasi oleh keluarga yang memiliki air bersih. ${ }^{12}$ Begitu pula dengan penelitian Aulia dkk tahun 2021 didapatkan bahwa ada hubungan antara ketersediaan air bersih dengan perilaku BABS dengan $p$ value 0,013 . Perilaku BABS lebih banyak ditemukan ada kelompok responden dengan ketersediaan air bersih yang tidak tersedia dibandingkan dengan kelompok responden dengan ketersediaan air bersih yang tersedia. ${ }^{13}$

Ketersediaan air bersih menjadi salah satu alasan rendahnya tingkat kepemilikan jamban di Desa Sungai Itik, dalam hal ini responden penelitian memerlukan peningkatan ketersediaan air bersih karena belum $100 \%$ responden memiliki sarana air bersih.

4. Hubungan Peran Petugas Kesehatan dengan Kepemilikan Jamban Sehat di Desa Sungai Itik Kecamatan Sadu Kabupaten Tanjung Jabung Timur Tahun 2021

Peran petugas kesehatan merupakan sebuah bentuk upaya pemberdayaan yang dilakukan kepada masyarakat yang bertujuan untuk meningkatkan kesadaran, kemampuan, pengetahuan, dan kemauan baik secara individu, keluarga maupun masyarakat dalam upaya mencegah terjadinya penyakit, meningkatkan derajat kesehatan dan menciptakan lingkungan yang sehat serta berperan aktif untuk menyelenggarakan setiap upaya kesehatan. Dalam melakukan pemberdayaan harus memperhatikan setiap situasi dan kondisi yang ada khususnya sosial budaya didaerah tersebut. ${ }^{3}$

Maksud peranan petugas kesehatan dalam penelitian ini yaitu adanya motivasi, bimbingan, 
dukungan, pemberdayaan maupun penyuluhan dari petugas kesehatan. Berdasarkan hasil wawancara peneliti kepada responden, didapatkan bahwa petugas kesehatan pernah melakukan penyuluhan kesehatan tentang pentingnya kepemilikan jamban namun tidak merata. Ada juga yang mengatakan bahwa petugas kesehatan tidak pernah datang apalagi memberikan edukasi. Namun, di Desa Sungai Itik terdapat bantuan dari pemerintah dengan menggunakan dana desa untuk keluarga yang tidak mampu membangun jamban berupa pembangunan jamban dirumah. Akan tetapi jumlahnya sangat terbatas. Tidak semua keluarga yang membutuhkan mendapatkan bantuan tersebut sehingga masih banyak keluarga yang tidak dapat membangun jamban sehat.

Perilaku merupakan aspek penting dalam pemanfaatan jamban sehat karena hal tersebut tidak akan dapat terwujud apabila masih belum ada kepercayaan dari masyarakat mengenai manfaat jamban sehat. Perlu dilakukan penyuluhan serta intensif dan berkelanjutan, namun apabila penyuluhan tidak mampu membentuk kepercayaan, hal tersebut berarti peran petugas masih belum mampu untuk membentuk kepercayaan masyarakat dalam merubah perilaku masyarakat terkait pemanfaatan jamban. Tenaga kesehatan merupakan salah satu hal yang berfungsi dalam upaya percepatan pembangungan kesehatan yang memiliki tugas di sarana akses pelayanan kesehatan masyarakat. ${ }^{14}$

Berdasarkan distribusi kuesioner didapatkan bahwa $87,5 \%$ responden yang mengatakan bahwa tindakan petugas kesehatan apabila melihat masyarakat yang masih belum memiliki jamban yang memenuhi syarat kesehatan yaitu dengan membiarkan saja. Sebaiknya, petugas kesehatan memberikan peringatan kepada responden yang belum memiliki jamban sehat. Selain itu, sebaiknya petugas kesehatan lebih rutin melakukan identifikasi permasalahan kepemilikan jamban sehat serta melakukan pemeriksaan ke rumah masyarakat.

Sejalan dengan penelitian yang dilakukan oleh Woodford dan Finny tahun 2018 yaitu terdapat hubungan antara peran petugas kesehatan dengan tersedianya jamban keluarga sehat di Desa Tompaso dengan $p$ value $=0,005 .{ }^{15}$ Penelitian ini juga didukung penelitian yang dilakukan oleh Laila dkk tahun 2018 yang didapatkan bahwa petugas kesehatan memiliki pengaruh secara signifikan terhadap perilaku kepala keluarga dalam pemanfaatan jamban pada masyarakat Desa Air Pinang Kecamatan Simeulue Timur Kabupaten Simeulue tahun 2018 dengan $p$ value $=0,007<$ $0,05 .{ }^{16}$ Kemudian sejalan dengan penelitian Sayati tahun 2018 yang menunjukkan bahwa ada hubungan antara peran petugas kesehatan dengan pemanfaatan jamban sehat. ${ }^{17}$

Namun penelitian ini tak sejalan dengan penelitian yang dilakukan Hayana dkk tahun 2020 yang di peroleh hasil uji statistik $p$ value 1,000 > $\alpha$ 0,005 yang berarti tidak ada hubungan antara peran petugas kesehatan dengan kepemilikan jamban sehat. Pada penelitian Hayana dkk ini menyebutkan bahwa kesadaran dari dalam diri masyarakat yang tinggi didasarkan oleh kemampuan dan kemauan sendiri dari individu sangat berkaitan dengan kepemilikan jamban sehat, hal ini dikarenakan kesadaran diri masyarakat yang tinggi akan meciptakan lingkungan yang sehat sehingga penting untuk diaplikasikan ke masyarakat. ${ }^{10}$

Peran petugas kesehatan memiliki pengaruh yang besar dalam peningkatan derajat kesehatan masyarakat. Penelitian ini menunjukkan bahwa peran petugas kesehatan sangat penting dalam mendorong keluarga untuk memiliki jamban sehat di rumah. Dorongan dapat berupa motivasi, penyuluhan, pemberdayaan ataupun pendampingan teknis.

\section{KESIMPULAN}

Pengetahuan, status ekonomi, ketersediaan air bersih dan peran petugas kesehatan merupakan faktor yang berhubungan dengan kepemilikan jamban sehat di Desa Sungai Itik Kecamatan Sadu Kabupaten Tanjung Jabung Timur Tahun 2021 dengan $p$ value $<\alpha$. 


\section{REFERENSI}

1. Syahrir S, Syamsul M, Aswadi, Surahmawati, Aeni S. Faktor - Faktor yang Berhubungan dengan Kepemilikan Jamban Keluarga di Wilayah Kerja Puskesmas Pertiwi Kota Makassar. Jurnal Higiene [Internet]. 2019;5(1):52-9. Available from:https://core.ac.uk/download/pdf/234747975.pdf

2. Anwar S, Aini S, Deovani B. Sosialisasi Pentingnya tidak Membuang Air Besar di Sungai (Stop BABS) di Desa Gampang Kecamatan Prambon. Abadimas Adi Buana [Internet]. 2017;01(1):43-8. Available from: http://jurnal.unipasby.ac.id/index.php/abadimas/article/view/679/551

3. Kementerian Kesehatan Republik Indonesia. Peraturan Menteri Kesehatan Republik Indonesia Nomor 3 Tahun 2014 tentang Sanitasi Total Berbasis Masyarakat [Internet]. 2014 p. 1-43. Available from: https://peraturan.bkpm.go.id/jdih/userfiles/batang/Permenkes_3_2014.pdf

4. Candrarini MR. Peran Puskesmas dalam Melaksanakan Program Sanitasi Pilar Stop Buang Air Besar Sembarangan. Higeia Journal Public Health Research Development [Internet]. 2020;4(1):100-7. Available from:

https://journal.unnes.ac.id/sju/index.php/higeia/article/download/32958/15628

5. Kementerian Kesehatan Republik Indonesia. Data, Temuan, dan Rekomendasi STBM [Internet]. Kementerian Kesehatan Republik Indonesia. 2018. Available from: http://stbm.kemkes.go.id/review_stbm/findings.html

6. Badan Perencanaan Pembangunan Nasional Republik Indonesia. Rencana Pembangunan Jangka Menengah Nasional 2020-2024 [Internet]. Badan Perencanaan Pembangunan Nasional Republik Indonesia. 2019. Available from: https://www.bappenas.go.id/files/rpjmn/Narasi RPJMN IV 2020-2024_Revisi 18 Juli 2019.pdf

7. Novitry F, Agustin R. Determinan Kepemilikan Jamban Sehat di Desa Sukomulyo Martapura Palembang. Jurnal IImu Kesehatan [Internet]. 2017;2(2):107-16. Available from: https://media.neliti.com/media/publications/217397-determinan-kepemilikan-jamban-di-d.pdf

8. Kementerian Kesehatan Republik Indonesia. Profil Sanitasi Total Berbasis Mayarakat Nasional [Internet]. Kementerian Kesehatan Republik Indonesia. 2019. Available from: http://monev.stbm.kemkes.go.id/monev/index.php/pilar_1/

9. Putra GS, Selviana. Faktor-faktor yang berhubungan dengan kepemilikan jamban sehat di desa empakan kecamatan kayan hulu. Jurnal Kesehatan Masyarakat Khatulistiwa. 2017;4(3):238-43.

10. Hayana, Raviola, Aryani E. Hubungan Cakupan Kepemilikan Jamban di Kelurahan Kampung Baru Kota Pekanbaru. Jurnal Kesehatan Global [Internet]. 2020;3(1):9-17. Available from: http://ejournal.helvetia.ac.id/iindex.php/jkg

11. Dewan Perwakilan Rakyat Republik Indonesia, Presiden Republik Indonesia. Undang-Undang Republik Indonesia Nomor 17 Tahun 2019 tentang Sumber Daya Air. 2019.

12. Mukhlasin, Solihudin EN. Kepemilikan Jamban Sehat pada Masyarakat. Faletehan Health Journal. 2020;7(3):119-23.

13. Aulia A, Nurhazuli, Darundiati YH. Perilaku Buang Air Besar Sembarangan (BABS) di Desa Kamal Kecamatan Larangan Kabupaten Brebes. Jurnal Kesehatan Masyarakat [Internet]. 2021;9(2):166-75. Available from: https://ejournal3.undip.ac.id/index.php/jkm

14. Apriyanti L, Widjanarko B, Laksono B. Faktor-faktor yang Mempengaruhi Pemanfaatan Jamban Keluarga di Kecamatan Jatibarang Kabupaten Brebes. Jurnal Promosi Kesehatan Indonesia. 2019;14(1):1-14.

15. Joseph WBS, Warouw F. Faktor-faktor yang Berhubungan dengan Tersedianya Jamban Keluarga Sehat di Desa Tompaso Dua Kecamatan Tompasso Barat Kabupaten Minahasa. Jurnal Kesehatan Masyarakat 
[Internet]. 2018;31-6. Available from:

https://ejournal.unsrat.ac.id/index.php/kesmas/article/download/22929/22625

16. Heranita L, Lubis NL, Moriza T. Faktor yang Mempengaruhi Perilaku Keluarga dalam Pemanfaatan Jamban di Pemukiman Desa Air Pinang, Kecamatan Simeulue Timur, Kabupaten Simeulue Tahun 2018. Jurnal Kesehatan Cehadum [Internet]. 2019;1(3):15-27. Available from: https://jkc.puskadokesa.com/index.php/jkc/article/download/27/11/

17. Sayati D. Faktor-faktor yang mempengaruhi pemanfaatan jamban sehat di wilayah kerja Puskesmas 23 llir Palembang. Jurnal 'Aisyiyah. 2018;2. 